\title{
Determination of the original coastline on Semarang city and Demak district using remote sensing approach
}

\author{
Ignatius Sriyana ${ }^{{ }^{*}}$, John Bosco Niyomukiza ${ }^{1,2}$, Sri Sangkawati ${ }^{1}$ and Sri Kumala \\ Parahyangsari ${ }^{3}$ \\ ${ }^{1}$ Department of Civil Engineering, Faculty of Engineering, Diponegoro University, Semarang, \\ Indonesia \\ ${ }^{2}$ Department of Civil Engineering, Faculty of Engineering, Ndejje University, Kampala, Uganda \\ ${ }^{3}$ Member of Watershed Coordination Forum in Central Java Province, Central Java, Indonesia
}

\begin{abstract}
Development of the coastal area without environmental consciousness is disrupting coastline equilibrium, thus triggering erosion and accretion. This results in the obscurity of the border area due to coastline change. The objective of this study is to determine the original coastline of Semarang city and Demak district. The method used is remote sensing using Landsat satellite imagery data dating from 1984 to 2018. The results showed that the length of the coastline in Semarang and Demak border coast shows a continuous increase from 48.2, 57.9, 63.7, and $73.5 \mathrm{~km}$ in 1984, 1992, 2000 , and 2008 , respectively to $92.6 \mathrm{~km}$ in 2018 , and the average annual change rate from 1984 to 1992,1992 to 2000,2000 to 2008 , and 2008 to 2018 is $1.2 \mathrm{~km}$ per year, $0.7 \mathrm{~km}$ per year, $1.2 \mathrm{~km}$ per year, and $2.1 \mathrm{~km}$ per year, respectively. It was concluded that the current coastline condition of Semarang city and Demak district has had an increase of $29.8 \mathrm{~km}$ in length and shifted inwards by $0.5-2 \mathrm{~km}$ in $2000-2018$ compared to the original coastline. This shows a deviation of 5-15\% from Government Regional Spatial Plan. The study recommends a sustainable coastal management and action plan to be prepared by the government, as it is vital in preserving the coastal regions.
\end{abstract}

\section{Introduction}

The coastline is one of the vital linear features on the earth's crust, and due to its dynamic and complex nature, it is sensitive to erosion and deposition [1-3]. It is, therefore, paramount to detect the coastal changes that could occur during specified periods. The disrupted coastal balance makes the coastline undergo frequent changes leading to both erosion and accretion [4]. By definition, a coastline is a boundary between the land and the water surface [1], [57], and it tends to retreat over $70 \%$ of the population across the globe that encounter coastal erosion [8]. Changes in coastline sometimes occur for a prolonged period due to geological occurrences. The issues of coastline change are continuously becoming a significant concern

* Corresponding author: sriyana@live.undip.ac.id 
to the environment, social and economic aspects across the globe [4, 7]. For that matter, the knowledge about coastline changes is essential in coastal management, more especially to countries with many islands like Indonesia. Absence of information about coastline changes lead to many disasters including negative effects to the surrounding environment [9].

Coastline change usually occurs due to different factors ranging from human activities to natural factors [10]. The natural factors include geology, weather condition, slope angle, waves and strength of the wind, and the amount of vegetation, whereas human factors include constructions, industrialization, mining, urbanization, and any other activity that intercepts free passage of sediments along the coast. According to Di et al. [11], it is crucial to detect and map the coastline, as it is important for safe navigation, sustainable coastal development and planning, coastal flood forecasting, resource management, and environmental protection [12-14]. Besides, it is important to determine the changes that occurred during different years for comparison purposes and help acquiring the information to forecast the future coastline changes. Previous studies have discussed about coastline changes, for example the study that was conducted in China showed that coastline change caused the Pearl River Estuary straitened and caused a lot of floods in the area [15]. The study that was done by Hussain et al. [16] showed coastline changes in the eastern part of Meghna Estuary, Bangladesh with a high magnitude and the major cause was sediment discharge from rivers. Alam and Kabir [17] examined morphological variations caused by erosion versus accretion in the coastal areas and offshore island of Bangladesh, and their study revealed that the areas were affected by accretion more than erosion during $1977-2010$. The cause of this phenomenon is the rising sea level that created accumulation of sediments. Tamassoki et al. [9] monitored shoreline changes in coastal city of Bandar Abbas using Landsat imaginary dated from 1984 to 2009 , and noticed a continuous increase in the shoreline length from $272 \mathrm{~km}$ to $330 \mathrm{Km}$ in 1984 to 2009, respectively. Their study revealed that the changes were caused by geological and hydrodynamic occurrences.

There are different methods of detecting the changes in the coastline, and among them include remote sensing approach, histogram thresholding, ground survey, aerial photography, and other methods $[6,18]$. However, remote sensing has proved to be the most effective method to assess the changes in coastal areas [19]. A lot of researches has been conducted using remote sensing to monitor the coastline changes affected by erosion and accretion [1, $7,20,21]$. Their results yielded success in the areas where they monitored coastlines using remote sensing. According to Hussain et al. [16], remote sensing provides the best solution as far as acquiring and processing data in a quick and faster way compared to other methods like photogrammetry. The objective of this paper is to determine the original coastline of Semarang city and Demak district in order to determine the original border area. This information is essential to the government because knowing the coastline change will enable them to understand the changing of physical environment better, thus developing coastal policies that will promote sustainable management practices. Besides, knowing the location and coastline changes is helpful to engineers while designing coastal protection structures. To achieve the objective of the current study, we used remote sensing approach using Landsat satellite imagery data dating from 1984 to 2018. 


\section{Materials and methods}

\subsection{Data and location}

The data needed in this research include; coastline length, area of abrasion and accretion that occurred during different years. The research was conducted along the coast with a length of $48.2 \mathrm{~km}$ at Demak district northern coastal area, starting from the coastline in Semarang city located at coordinate $6^{\circ} 55^{\prime} 58.81^{\prime \prime} \mathrm{S}, 110^{\circ} 27^{\prime} 53.20^{\prime \prime} \mathrm{E}$ and ending at coordinate $6^{\circ} 42^{\prime} 19.98^{\prime \prime} \mathrm{S}$, $110^{\circ} 37^{\prime} 2.18^{\prime \prime} \mathrm{E}$, as presented in Figure 1. This region marked the northern part of the waters of Java Island.

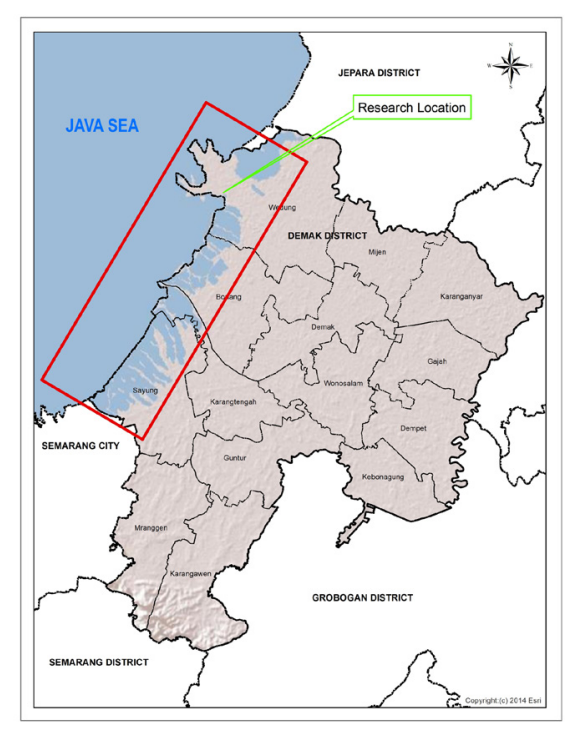

Fig. 1. Location of the study area.

\subsection{Sampling method}

The samples were gathered at two distinct spots: the first one at Semarang city at coordinate $6^{\circ} 56^{\prime} 57.24^{\prime \prime} \mathrm{S}-110^{\circ} 26^{\prime} 34.15^{\prime \prime} \mathrm{E}$ and the second one at the end of coastline in Demak district at coordinate $6^{\circ} 42^{\prime} 26.33^{\prime \prime} \mathrm{S}-110^{\circ} 36^{\prime} 55.84^{\prime \prime} \mathrm{E}$. The samples were taken from these coordinates to identify the differences in the coastline from 1984 to 2018.

\subsection{Analytical technique}

Data used in this research was obtained from Landsat satellite imagery recorded on 23 February 1984, 28 June 1992, 23 April 2000, 24 April 2008, and a drone captured on 5 June 2018. The overlay from Landsat images and RGB overhead images were corrected through radiometric and geometric check (see Figure 2) and also integrated with the administrative limit from Morosari district in Demak regency and the border of Semarang City (Tanjungmas district).

The processing method of the Landsat images consists of several steps as listed below;

- The initial stage of data development is conducted through correlation with the standard procedure issued by the data supplier. 
- Early development began by synchronizing the spatial resolution between Landsat-4 MSS and Landsat series TM.ETM+. This process is done by resampling the Landsat MSS data so that the spatial resolution turns into 30 meters through cubic B-Spline algorithm and then followed by a geometric check on this Landsat data; thus the north and south value of the imaging is identical to the one on map (administration map) and can be overlaid on each other.

- The development of RGB (Red Green Blue) composite for each imaging acquisition.

- Digitizing the fourth RGB image as an analogy by digitalizing it on screen.

- Analysis and calculation are done through the process of digitizing of each year's image so that it is possible to find out the changes both from accretion and abrasion.

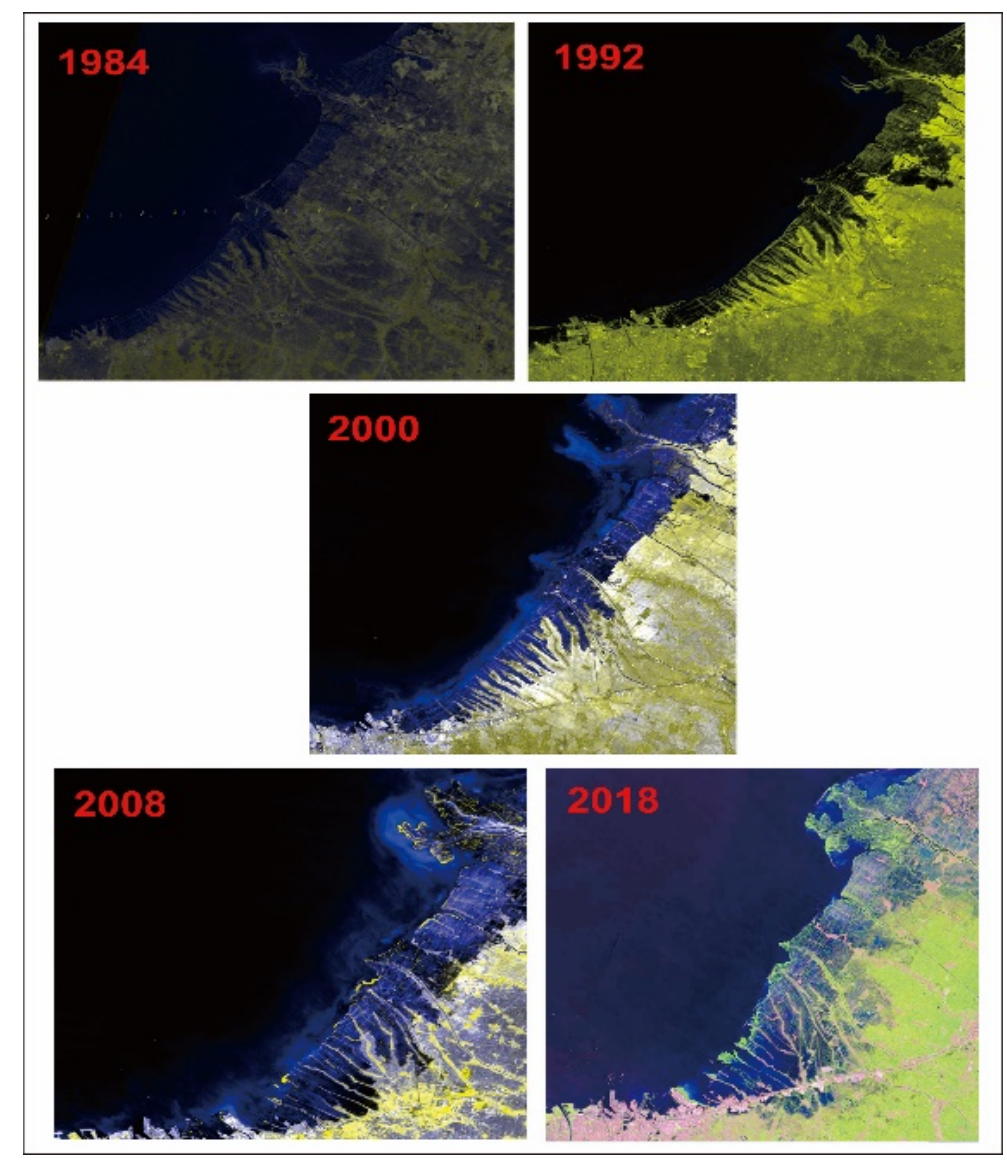

Fig. 2. Landsat Imaging (1984-2018).

\section{Results and Discussions}

\subsection{Landsat Imaging Coastline Analysis}

The correction results are done through manual works (on-screen digitation). The results of the coastline changes can be seen in Figure 3. According to the coastline length calculation resulted from digitation, the lengths of the border area between Semarang and Demak 
(Tanjung Mas, Terboyo Wetan, Terboyo Kulon, and Trimulyo village, and villages along the coast in Demak district) were $48.2 \mathrm{~km}, 57.9 \mathrm{~km}, 63.7 \mathrm{~km}, 73.5 \mathrm{~km}$, and $92.6 \mathrm{~km}$ in 1984 , 1992, 2000, 2008, and 2018, respectively. As a result, the rate of coastline changes in 1984 to 1992,1992 to 2000,2000 to 2008 , and 2008 to 2018 is $1.2 \mathrm{~km}$ per year, $0.7 \mathrm{~km}$ per year, $1.2 \mathrm{~km}$ per year, and $2.1 \mathrm{~km}$ per year, respectively (see Table 1 ). It was noticed that a big incline $(28.9 \mathrm{~km})$ occurred in $2000-2018$.

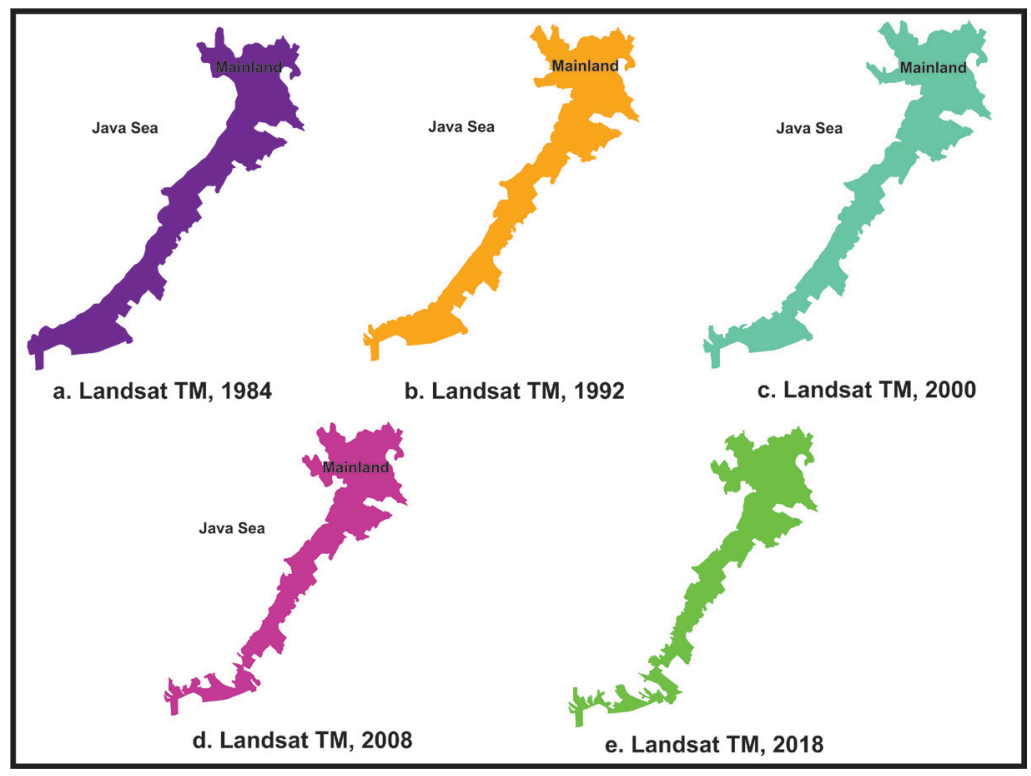

Fig. 3. Coastline information, digitation result from Landsat imaging from 1984 to 2018.

Table 1. Coastline length and the rate of coastline changes in 1984 to 2018.

\begin{tabular}{|c|c|c|}
\hline Year & Coastline length (Km) & $\begin{array}{c}\text { Rate of coastline } \\
\text { changes(Km/year) }\end{array}$ \\
\hline 1984 & 48.2 & - \\
\hline 1992 & 57.9 & 1.2 \\
\hline 2000 & 63.7 & 0.7 \\
\hline 2008 & 73.5 & 1.2 \\
\hline 2018 & 92.6 & 2.1 \\
\hline
\end{tabular}

The occurrence of abrasion and accretion in an area was identified by integrating two results of the digitized coastline imaging from different years. The results of integration and digitization from consecutive years are seen in Figure 3.

Abrasion and accretion occured in Demak district and Semarang city with different sizes in different years, as shown in Table 2. In the period between 1984 to 1992, the largest abrasion occurred in Sayung sub-district, and a small part of it occurred in Karangtengah, Wedung, Bonang, Genuk, and north Semarang district as seen in Figure 4 (a) within a total area of 846.5 ha. The reason for this big abrasion occurrence in Sayung could be its location that is open without any human or natural protection, thus easily eroded in case the waves advance to the land [3]. Figure 4 (b) depicts the accretion-affected areas, where the most dominant accretion occurred in Karangtengah, Sayung, Wedung, and north Semarang with a total area of 496.5 ha (see Table 2). According to Xu [10], other than natural factors, manmade factors also play a major role in coastline changes, for example coastline protection 
structures and beach nourishment projects that are built to reduce coastal erosion may lead to artificial accretion of the coastline. The overall abrasion that occurred in $1984-2018$ in Semarang city and Demak district is higher than the accretion values. The abrasion affected people highly. The area that was previously used as settlement was covered by water.

Table 2. Abrasion and Accretion area at the border of Demak district and Semarang city.

\begin{tabular}{|c|c|c|c|c|c|c|c|c|c|c|}
\hline \multirow[b]{2}{*}{$\begin{array}{l}\mathrm{N} \\
\mathrm{o}\end{array}$} & \multirow[b]{2}{*}{ Sub-district } & \multirow[b]{2}{*}{$\begin{array}{c}\text { City/ } \\
\text { District }\end{array}$} & \multicolumn{2}{|c|}{ 1984-1992 } & \multicolumn{2}{|c|}{$1992-2000$} & \multicolumn{2}{|c|}{$2000-2008$} & \multicolumn{2}{|c|}{ 2008-2018 } \\
\hline & & & $\begin{array}{c}\text { Abr } \\
\text { asio } \\
n\end{array}$ & $\begin{array}{l}\text { Accr } \\
\text { etion } \\
\text { (Ha) }\end{array}$ & $\begin{array}{c}\text { Abra } \\
\text { sion } \\
\mathrm{Ha})\end{array}$ & $\begin{array}{l}\text { Accr } \\
\text { etion } \\
\text { (Ha) }\end{array}$ & $\begin{array}{c}\text { Abra } \\
\text { sion } \\
\mathrm{Ha})\end{array}$ & $\begin{array}{l}\text { Accr } \\
\text { etion } \\
\text { (Ha) }\end{array}$ & $\begin{array}{l}\text { Abra } \\
\text { sion } \\
(\mathrm{Ha})\end{array}$ & $\begin{array}{l}\text { Accr } \\
\text { etion } \\
\text { (Ha) }\end{array}$ \\
\hline 1 & $\begin{array}{l}\text { Karangtenga } \\
\mathrm{h}\end{array}$ & Demak & 77.9 & 11.4 & 35.5 & 22.1 & 8.2 & 40.1 & 11.2 & 8.7 \\
\hline 2 & Sayung & Demak & $\begin{array}{c}258 . \\
8\end{array}$ & 5.9 & $\begin{array}{c}128 . \\
8\end{array}$ & 0.1 & $\begin{array}{c}390 . \\
2\end{array}$ & 9.2 & $\begin{array}{c}460 . \\
6\end{array}$ & 0.4 \\
\hline 3 & Wedung & Demak & $\begin{array}{c}131 . \\
1\end{array}$ & 1.6 & 80.1 & $\begin{array}{c}152 . \\
4\end{array}$ & 86.2 & $\begin{array}{c}311 . \\
9\end{array}$ & $\begin{array}{c}190 . \\
8\end{array}$ & 82.7 \\
\hline 4 & Bonang & Demak & $\begin{array}{c}175 . \\
3\end{array}$ & 0 & 18.9 & 39.7 & 3.7 & $\begin{array}{c}103 . \\
4\end{array}$ & 69.4 & 0.1 \\
\hline 5 & Genuk & $\begin{array}{l}\text { Semaran } \\
\mathrm{g}\end{array}$ & 80.5 & 0 & 45.9 & 0 & $\begin{array}{c}141 . \\
1\end{array}$ & 17.1 & $\begin{array}{c}152 . \\
9\end{array}$ & 21.7 \\
\hline 6 & $\begin{array}{l}\text { North } \\
\text { Semarang }\end{array}$ & $\begin{array}{l}\text { Semaran } \\
\mathrm{g}\end{array}$ & $\begin{array}{c}122 . \\
9\end{array}$ & $\begin{array}{c}477 . \\
6\end{array}$ & 40.7 & 27.4 & 53.3 & 11.5 & 25.1 & 13.2 \\
\hline & Total & & $\begin{array}{c}846 . \\
5\end{array}$ & $\begin{array}{c}496 . \\
5\end{array}$ & $\begin{array}{c}349 . \\
9\end{array}$ & $\begin{array}{c}241 . \\
7\end{array}$ & $\begin{array}{c}682 . \\
7\end{array}$ & $\begin{array}{c}493 . \\
2\end{array}$ & 910 & $\begin{array}{c}126 . \\
8\end{array}$ \\
\hline
\end{tabular}

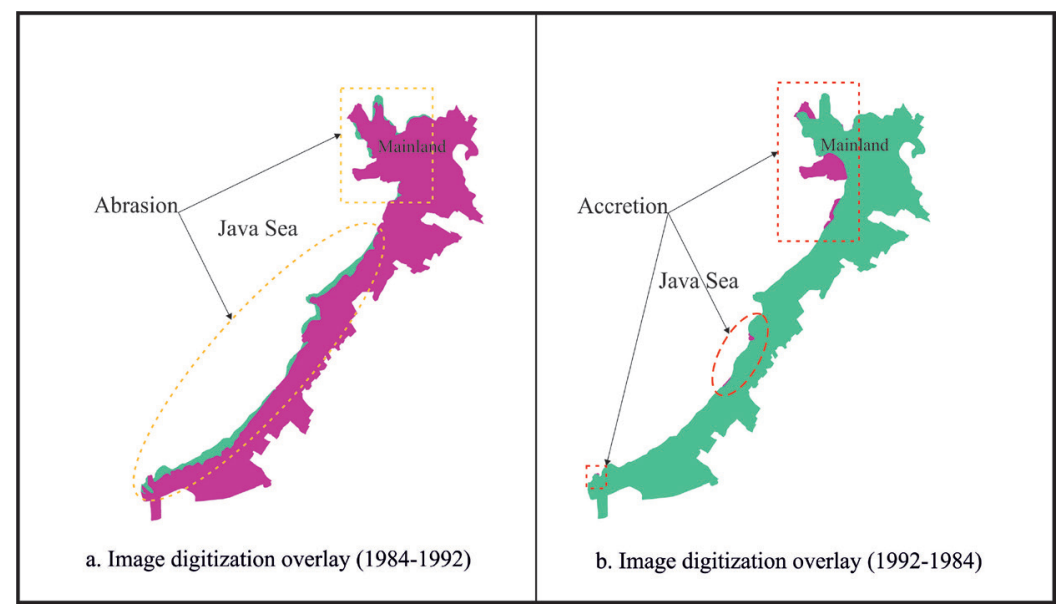

Fig. 4. Satellite imaging result of coast abrasion and accretion information.

Figure 5 (a) shows the location where the abrasion process happened in 1992 to 2000. Abrasion took place in Karangtengah, Sayung, Wedung, Bonang, Genuk, and north Semarang with a total area of 349.9 ha. Figure 5 (b) shows the regions where accretion occurred in Karangtengah, Sayung, Bonang, Wedung, and north Semarang with a total area of 241.7 ha. 


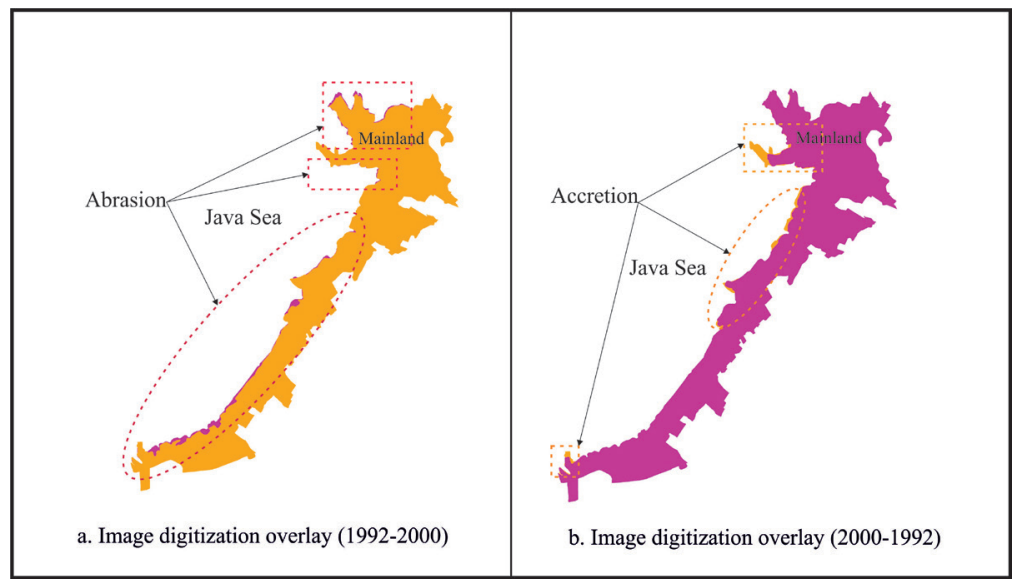

Fig. 5. Landsat satellite imaging result of coast abrasion and accretion $1992-2000$.

Abrasion process that occurred in the period 2000-2008 was relatively the same as the previous period (1992-2000) but a bit different, as seen in Figure 6 (a). Abrasion occurred in Karangtengah, Sayung, Wajah, Bonang, Genuk, and north Semarang, with a total area of 682.7 ha. Figure 6 (b) shows the areas where accretion occurs, where the most dominant occurred in the sub-districts of Wedung, Karangtengah, Sayung, Bonang, Genuk, and north Semarang with an overall area of 493.2 ha (see Table 2).

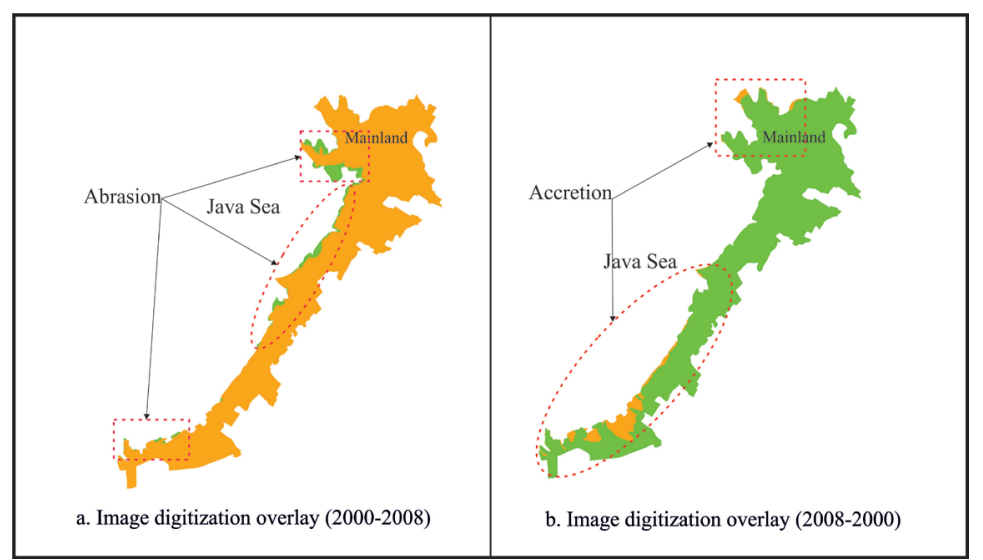

Fig. 6. Landsat satellite imaging result of coast abrasion and accretion $2000-2008$.

Figure 7 (a) shows the location where the abrasion process occurred between 2008 and 2018. It was seen that the magnitude of abrasion in this period is relatively larger than the previous periods. Abrasion occurred in Karangtengah, Sayung, Wajah, Bonang, Genuk, and north Semarang district with a total area of 910 ha. Whereas Figure 7 (b) shows the areas where accretion occurred, the most dominant accretion occurred in the sub-districts of Wedung, Karangtengah, Sayung, Bonang, Genuk, and north Semarang with a total area of 126.8 ha (see Table 2). 


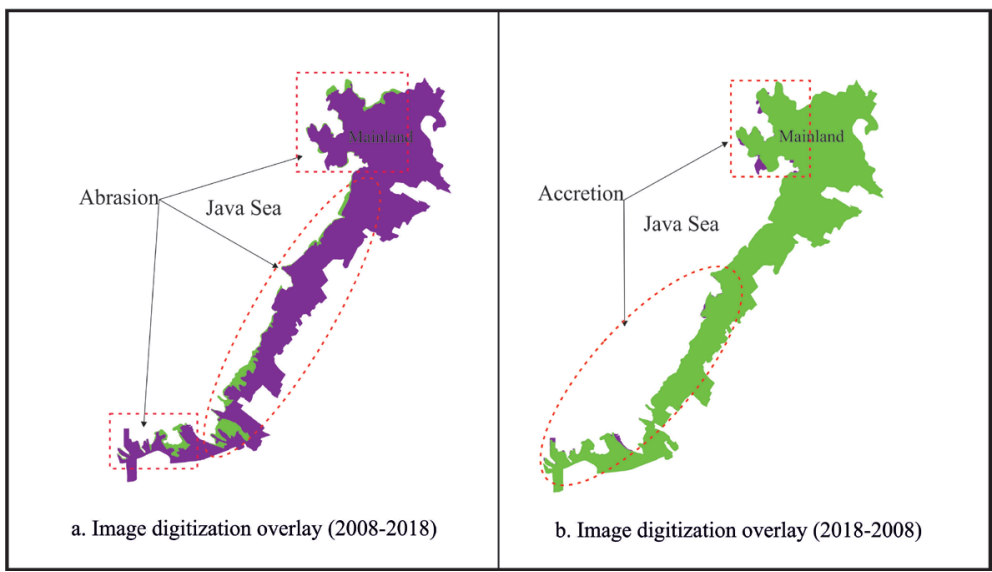

Fig. 7. Landsat satellite imaging result of coast abrasion and accretion $2008-2018$.

Figure 8 (a) shows that the coastline accretion process that seems to have been caused by sedimentation processes carried out by river flow, sea, and human activities like fishing, and the permanent settlement around the coast, while the coastline abrasion process as seen in Figure 8 (b) is due to the erosion caused by sea waves, sea level rise, currents, and other factors. By observing Figure 8, it can be deduced that the coastline's accretion is caused by sedimentation and land use changing into dikes, whereas the abrasion process can be assumed to be caused by the erosion due to sea waves.

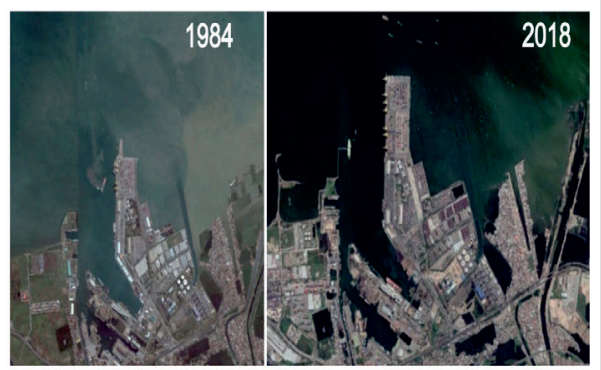

a. The process of coastline accretion at the port of Tanjungmas, Semarang city
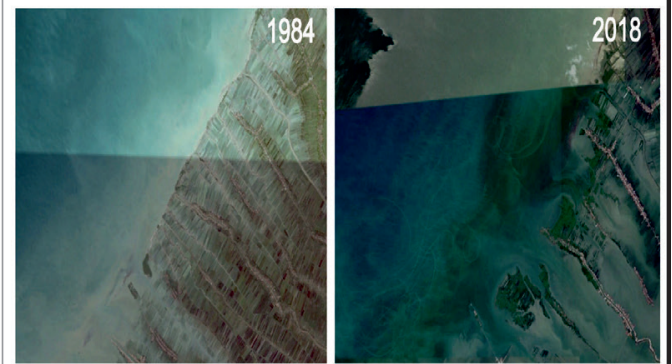

b. The process of coastline abrasion at Sayung Subdistrict, Demak district

Fig. 8. Accretion and Abrasion (1984 - 2018).

When the results of the digitization of the coastline are fully integrated (see Figure 9), it is seen that the change in the coastline only occurs in the cape. If there is river flow in the cape, then the accretion process occurs in agricultural areas/ponds such as in Sayung subdistrict, Bonang, Karangtengah. On the other hand, if there is no river flow, there will be an abrasion process, for example, the one that happened in Wedung sub-district while the accretion process occurred in Tanjung Mas Port, and north Semarang. 


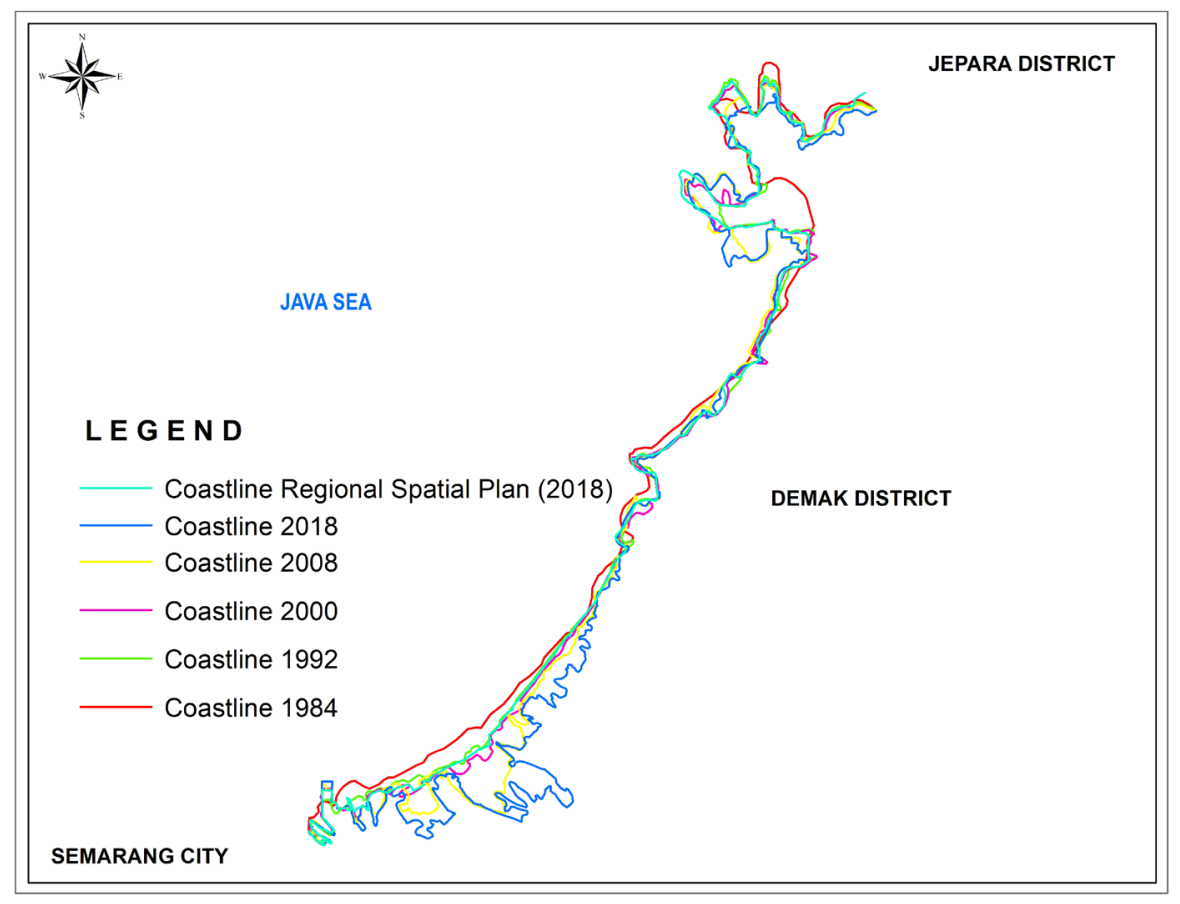

Fig. 9. Coastline change at the study location.

\subsection{Comparative analysis of Regional Spatial Plan and Landsat Imaging data}

Based on the Spatial Planning of Semarang City and Demak Regency (2011-2031), the length of the coastline in the study location (Semarang city and Demak regency) is $62.8 \mathrm{~km}$. While the length of the coastline based on remote sensing analysis using Landsat satellite image is $92.6 \mathrm{~km}$. This shows that there is a difference of $29.8 \mathrm{~km}$ (see Figure 10). Analysis by Landsat satellite image gives a larger length compared to the one provided by Regional Spatial Plan 2011-2031. 


\section{ICENIS 2020}

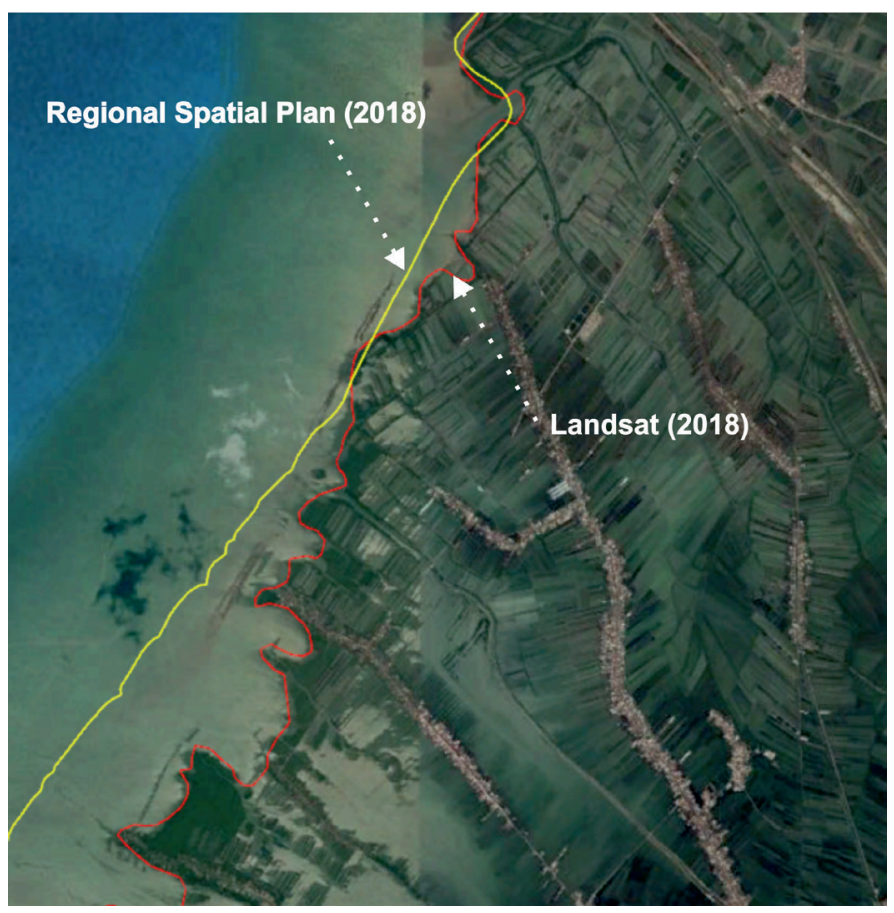

Fig. 10. Coastline change in 2018 according to Regional Spatial Plan and analysis from Landsat Imaging.

\section{Conclusion}

This study investigated the coastline changes that occurred at the boundary of Semarang city and Demak district. The data from the Regional Spatial plan was compared to the data analysis from Landsat imaging. It was found out that the coastline underwent abrasion $(1,592.7 \mathrm{ha})$ and accretion (620 ha) from 2000 to 2018 . The major factors that contributed to the abrasion are sea waves, currents, and storms, while the factors that contributed to accretion are human activities like fishing, and the permanent settlement around the coast. The coastline determination by Government Regional Spatial Plan deviates from the original coastline condition by $5-15 \%$. The study recommends a sustainable coastal management and action plan to be prepared by the government. This will be essential in preserving the coastal regions. 


\section{References}

1. A. A. Alesheikh, A. Ghorbanali, and N. Nouri, Int. J. Environ. Sci. Technol., 4(1), 6166 (2007)

2. S. Kaliraj, N. Chandrasekar, and K. K. Ramachandran, J. Remote Sens. Sp. Sci., 20(2), 265-282 (2017)

3. I. A, S. Anggoro, T. R. Soeprobowati, M. Helmi, and A. S. Khair, Jurnal Pendidikan IPA Indonesia, 8(1), 1-11 (2019)

4. S. Maiti and A. K. Bhattacharya, Mar. Geol. 257(1), 11-23 (2009)

5. A. Guariglia, A. Buonamassa, A. Losurdo, and R. Saladino, Ann. Geophys., 49(1), 295304 (2006)

6. A. Sabuncu, H. Ozener, and B. Turgut, Int. Arch. Photogramm. Remote Sens. Spat. Inf. Sci.,41(July), 1169-1174 (2016)

7. U. Natesan, A. Parthasarathy, R. Vishnunath, G. E. J. Kumar, and A. Ferrer, Aquat. Procedia, 4, 325-332 (2015)

8. K. A. Addo, M. Walkden, and J. P. Mills, ISPRS J. Photogramm. Remote Sens., 63, 543-558 (2008)

9. E Tamassoki, H. Amiri, and Z. Soleymani, IOP Conf. Ser. Earth Environ. Sci., 20, 1-9 (2014)

10. N. Xu, Atmosphere (Basel)., 9(3),107 (2018)

11. K. Di, R. Ma, J. Wang, and R. Li, "Coastal Mapping and Change Detection Using HighResolution IKONOS Satellite Imagery, In Proceedings of the 2003 annual national conference on Digital government research, (2003)

12. S. Kurt, A. Karaburun, and A. Demirci, Sci. Res. Essays, 5(19), 3009-3017 (2010)

13. H. Liu and K. C. Jezek, Int. J. Remote Sens., 25(5), 937-958 (2004)

14. C. Liu, J. Yang, J. Yin, and W. An, IEEE J. Sel. Top. Appl. Earth Obs. Remote Sens., 9(11), 4908-4920 (2016)

15. X. Li and M. C. Damen, J. Mar. Syst., 82, S54-S61 (2010)

16. M. A. Hussain, Y. Tajima, K. Gunasekara, S. Rana, and R. Hasan, IOP Conf. Ser. Earth Environ. Sci, 20, 1-10 (2014).

17. A. M Shamsul and U. Kabir, Am. J. Geogr. Inf. Syst., 2(1), 15-18 (2013)

18. R. Gens, Int. J. Remote Sens., 31(7), 1819-1836 (2010)

19. E. P. Green, P. J. Mumby, A. J. Edwards, and C. D. Clark, Coast. Manag., 24(1), 1-40 (1996)

20. P. Chand and P. Acharya, Int. J. Geomatics Geosci., 1(3), 436-455 (2010)

21. A. Parthasarathy and U. Natesan, Nat. Hazards, 75(2), 1713-1729 (2015) 